\title{
A Good Enough Heart: Kant and the Cultivation of Emotions
}

\author{
KRISTA K. THOMASON \\ Swarthmore College \\ Email: kthomas2@swarthmore.edu
}

\begin{abstract}
One way of understanding Kant's views about moral emotions is the cultivation view. On this view, emotions play a role in Kantian morality provided they are properly cultivated. I evince a sceptical position about the cultivation view. First, I show that the textual evidence in support of cultivation is ambiguous. I then provide an account of emotions in Kant's theory that explains both his positive and negative views about them. Emotions capture our attention such that they both disrupt the mind's composure and serve as a surrogate for reason. As such, Kant cannot recommend that we cultivate our emotions.
\end{abstract}

Keywords: Kantian moral psychology, emotions, cultivation, virtue

One of the common ways of understanding Kant's views about emotions is what I will call the cultivation view. ${ }^{\mathrm{I}}$ The cultivation view is not univocal, but versions of it share a primary conclusion: emotions can play a role in Kantian morality provided they are properly cultivated. ${ }^{2}$ On this interpretation, emotions are a key part of the development of and the expression of moral sensitivity; they help us to notice when the concerns of morality are salient (cf. Baron I995: 220; Sherman I997: I46). They function as a 'pair of moral eyes' that allow us to see where our moral obligations arise in the world (Guyer I993: 389). If we accept the cultivation view, the question arises: what precisely does it mean to 'cultivate' an emotion and how exactly do we go about doing so? Unfortunately, Kant says painfully little about this. Once we start to examine how cultivation is supposed to work, however, we discover more problems than we solve. It is my aim in this paper to evince a sceptical position about the cultivation view: I will argue that Kant does not believe we should try to cultivate emotions or emotional sensitivity. ${ }^{3}$ 
Here I set aside what I will call 'specialized' emotions such as the moral feeling, respect and practical love, which Kant usually discusses separately and in more detail. ${ }^{4}$ I focus instead on emotions like sympathy, joy or anger because one of the attractions of the cultivation view is that it allows emotions like these to play a positive role in Kant's moral theory. ${ }^{5}$ The paper has two main parts. First, I begin by examining the primary textual evidence for the cultivation view to show that it is more ambiguous than it might appear. Evincing a sceptical position about emotional cultivation requires providing alternative explanations for Kant's ambivalence about emotions. Kant seems to hold negative and positive views about emotions throughout his work, and advocates of the cultivation view can explain why: they can argue that he praises cultivated emotions and warns against uncultivated emotions. The second part of the paper offers an account of emotions in Kant's theory. Kant thinks that emotions are particular types of sensations that capture our attention in a unique way. This feature of emotions explains how they can both disrupt the mind's composure and yet also serve as a moral surrogate before reason is strong enough. On my reading, Kant can coherently reject emotional cultivation and at the same time attribute a positive role to emotions.

\section{Cultivated Emotions}

The advantage of the cultivation view is that it answers two important interpretative challenges about emotions in Kant's theory. First, Kant is notoriously ambivalent about emotions. In the Groundwork, he famously claims that rational agents naturally wish to be rid of emotions $(4: 428)$. Yet in the Doctrine of Virtue, Kant claims that we have a duty to 'cultivate the compassionate natural (aesthetic) feelings in us' (MM, 6: 457). We can see this notorious 'teeter-totter' on emotions throughout his writings. ${ }^{6}$ The other challenge is the centrality of the motive of duty to Kantian moral theory. The primacy of the motive of duty constrains the role that emotions can play in morality: whatever emotions do, they cannot unseat duty as the primary moral motive. ${ }^{7}$ The cultivation view answers the first challenge by arguing that Kant is not critical of all emotions; he is critical of them only when they are overpowering, capricious or challenging to the sovereignty of reason (cf. Baron 1995: 202-3; Sherman 1997: 167-70). Baron, for example, argues that Kant's negative remarks about emotions are actually critiques of sentimentality, which occurs when we are passive towards our emotions and allow ourselves to be carried away by them (I995: I96). The cultivation view answers the second challenge by arguing that emotions do not provide the basis for moral action. They are rather complements to duty and their cultivation itself can be a duty. Emotions function as 'natural ... 
receptivities' to morality (Sherman I997: I25). That is, they can both help moral agents to become aware of morally salient features of the world and can be part of moral responses. Sympathy, for example, allows us to register the needs of others so that we know when the duty of beneficence is called for (Herman I993: 8I-2; Guyer I993: 388-9). Properly cultivated emotions are subordinate to or compatible with reason (Herman I993: 3I-2; Baron 1995: 2I5; Sherman 1997: I68; Guyer 20IO: I46-8). Cultivated emotions can thus play a valuable role in Kant's moral theory.

How then do we go about cultivating our emotions? It would be a mistake to expect from Kant a detailed programme about the task of emotional cultivation, yet the textual evidence is particularly scarce. If Kant takes the task of cultivating feelings seriously, it is reasonable to expect at least some hint about how this works. Precisely the place where we might expect to find clarification on cultivation is in the Doctrine of Methods of Ethics. Yet here we find familiar Kantian language about reason controlling emotion rather than cultivating it: virtue is the 'strength of ... resolution in conflict with powerful opposing inclinations', where 'reason gains ascendancy' (MM, 6: 477). As Cohen shows, Kant's Lectures on Pedagogy warn against cultivating emotions in children because they risk being unable to control their feelings and risk confusing a good heart with a sense of duty (2016: 5 $\left.{ }^{\mathrm{I} 2-\mathrm{I} 3} 3\right)^{8}$ Indeed, in the moral catechism in the Doctrine of Methods, the teacher asks the pupil what he would do if he controlled all the happiness in the world. The pupil responds that he would share it with others so that they could be happy as well. The teacher then responds by saying, 'Now that proves you have a good enough heart; but let us see whether you have a good head to go along with it' (MM, 6: 480, emphasis in original). It should strike readers as odd that Kant not only does not provide more information about emotional cultivation in the places where it might naturally appear, but that he also seems to deny that moral education should involve emotional cultivation.

When Kant does talk about emotional cultivation, it seems to have at least three different meanings. First, he often equates it with strengthening. When Kant discusses cultivation of moral feeling, for example, he claims that our obligation is not to acquire it, but to 'cultivate it and strengthen it through wonder at its inscrutable source' ( $M M, 6: 400$, emphasis in original). Equating 'cultivate' with 'strengthen' also seems to be one of the readings of section 35 in the Doctrine of Virtue where Kant claims we must cultivate natural sympathetic feelings $(M M, 6: 457)$. I will return to this passage in more detail shortly, but we can see that 'strengthen' is at least one of the 
meanings of 'cultivate'. Elsewhere, Kant seems to suggest that cultivation requires paying careful attention. ${ }^{9}$ He claims for example that cultivating one's conscience requires one to 'sharpen one's attentiveness to the voice of the inner judge' (MM, 6: 40I). While conscience does not seem to be an emotion, it is not unreasonable to think that cultivating emotions also requires attentiveness. This reading might help explain why we ought to wonder at the inscrutable source of moral feeling. Finally, cultivation sometimes seems to mean refining. ${ }^{\text {IO }}$ Kant claims that we have a duty of selfperfection, which consists in part in 'cultivating one's faculties (or natural predispositions)', which involves raising ourselves from 'the crude state' of our nature 'more and more toward humanity' ( $M M, 6: 387$, emphasis in original). ${ }^{\text {II }}$ On this reading, cultivation is the process through which we refine the crude or merely natural parts of ourselves to be worthy of our dignity (Papish 2007: 137-8). Although all of these meanings of cultivation are suggestive, we need to investigate further in order to see how exactly how we are supposed to undertake this task. In what follows, I will examine some of the clearest textual evidence for emotional cultivation and raise questions about it.

\section{Section 35 and Cultivating Sympathy}

Section 35 is perhaps the strongest evidence to support the claim that Kant thinks we can and should cultivate emotions. ${ }^{\mathrm{I}}{ }^{2}$ I quote the passage in full:

But while it is not in itself a duty to share the sufferings (as well as the joys) of others, it is a duty to sympathize actively in their fate; and to this end it is therefore an indirect duty to cultivate the compassionate natural (aesthetic) feelings in us, and to make use of them as so many means to sympathy based on moral principles and the feeling appropriate to them. It is therefore a duty not to avoid the places where the poor who lack basic necessities are to be found but rather to seek them out, and not to shun sick rooms or debtors' prisons and so forth in order to avoid sharing painful feelings one may not be able to resist. For this is still one of the impulses that nature has implanted in us to do what the representation of duty alone might not accomplish. (MM, 6: 457)

Here Kant explicitly states that it is our 'indirect duty' to cultivate our natural feelings of sympathy. The passage appears to suggest that cultivation of sympathy requires that we expose ourselves to situations where sympathy is aroused in order to strengthen it. Baron interprets the passage this way, writing that 'to cultivate [sympathy] we are to put ourselves in situations that will foster painful sympathetic feelings' (I995: 215). Sherman also adopts 
this reading: 'We need to cultivate [sympathy] - visiting debtors' prisons and sick beds - in order to orient these sensitivities appropriately, in this case, toward the need and poverty that are potential occasions for beneficence' (I997: I45). Likewise, Guyer explains that 'visiting sick rooms and debtors prisons ... will supposedly strengthen our natural disposition to sympathy' (20I0: I46). Based on this passage, we might conclude that in order to cultivate sympathy we must seek out occasions to feel it.

The claim about exposing ourselves to situations where we will feel sympathy is, however, not as clear as it first appears. This passage follows the passage about Kant's imagined Stoic who rejects compassion when he cannot help his friend (cf. Denis 2000). Immediately after the discussion of the Stoic, Kant bolsters his claim about not sharing in the sufferings of others. He writes: 'In fact, when another suffers ... and I let myself be infected by his pain ... then two of us suffer ... But it cannot possibly be a duty to increase the ills of the world and so to do good from compassion' (MM, 6: 457, emphasis in original). We cannot, in other words, expect that we have an obligation to make ourselves suffer because someone else is suffering. Since section 35 follows directly after the Stoic passage, there is reason to read it in close relation to Kant's praise for the Stoic. ${ }^{33}$ Kant could be qualifying the point he has just made about not having a duty to increase the ills of the world. The section begins in exactly this way: he writes, 'while it is not a duty to share the sufferings (as well as the joys) of others, it is a duty to sympathize actively in their fate' (MM, 6:457). It is 'to this end' that we are to 'cultivate the compassionate natural ... feelings in us, and to make use of them as so many means to sympathy based on moral principles' (ibid.). In other words, since Kant has just claimed that we ought not increase the ills of the world by feeling the pain of others, a Stoic-minded reader might conclude that she should thus try to extirpate her natural sympathetic feelings. In section 35, Kant rejects this implication. Just because we have no duty to feel the pain of others, it does not then mean that we should try to get rid of our sympathetic feelings.

Given the context of the sympathy passage, section 35 may not be a recommendation to go to sick rooms and debtors' prisons to cultivate sympathy, but rather a warning to those who would try to avoid unpleasant feelings. At the end of the passage Kant writes: 'For this [the painful sympathy we are unable to resist] is still one of the impulses that nature has implanted in us to do what the representation of duty alone might not accomplish' (MM, 6:457). Although much of the attention on this line has focused on the question of whether sympathy can act as a motive, ${ }^{\mathrm{I}}{ }^{4}$ I want to call attention to the first part. Kant is picking up on 
the previous sentence where he has claimed that we should not try to avoid painful sympathetic feelings that we might be unable to resist. Those painful feelings are 'still one of the impulses' that nature has given us - they are not, in other words, something bad or burdensome that we should avoid as the Stoic does. Read this way, section 35 contains a milder claim: even though we have no duty to feel sad for the sufferings of others, we are not allowed to beg off our duty to care about the plight of others to spare ourselves sadness or pain. Kant's claim might be addressed to someone who is tempted to avoid places where people are in need because she is trying to spare herself painful feelings - she takes the story of the imagined Stoic too literally and so decides to refuse to confront the sufferings of others at all. On this reading, debtors' prisons and sick rooms are examples of places where people are suffering and are in need of help, and yet are also places we might be particularly keen to avoid because they are so sad. Kant may be simply arguing against the temptation we might have to ignore people in need because we do not want to burden ourselves with their pain. ${ }^{15}$ We should seek these places out because the people there need our help, but not because they are good places to practise sympathy. If this is right, 'cultivating' our natural sympathetic impulses may just be a contrast to whatever the Stoic might do - extirpate, avoid or detach from those feelings. In saying we should cultivate our feelings, Kant might just be saying: do not try to get rid of them or see them as a burden.

Advocates of the cultivation view will naturally point to Kant's claim that we have a duty to cultivate active sympathy, or the 'capacity and the will to share in others' feelings' (MM, 6: 456, emphasis in original). On this reading, Kant is claiming that we must cultivate sympathy by refining our natural capacities rather than strengthening them. Fahmy, for example, argues that when we expose ourselves to situations where we feel sympathy, we will then be 'in a position to evaluate [our] feelings on the basis of moral principles' (2009: 38). Read this way, Kant seems to suggest that our natural sympathetic feelings are the raw material that we refine into active sympathy. Indeed, he claims that active sympathy is the 'end' in the service of which we should 'cultivate the compassionate natural (aesthetic) feelings in us' (MM, 6: 457).

The trouble is that the relationship between our natural sympathetic feelings and active sympathy (whatever that amounts to) is unclear. ${ }^{16}$ When we go to sick rooms and debtors' prisons, we are exposing ourselves to 'painful feelings [we] may not be able to resist' (MM, 6:457, my emphasis). The kind of sympathy that we are trying to avoid by not visiting sad places is the kind that belongs to our 'receptivity' to others' 
feelings that is 'given by nature itself' that Kant references in the beginning of the section ( $M M, 6: 456)$. This is clearly pathological or passive sympathy and Kant is clear that we have no obligation to develop it (ibid.). He is even disparaging of passive sympathy, calling it 'unfree' and 'communicable' like a 'contagious disease' (ibid.). If pathological sympathy is the raw material we refine into active sympathy, how do we train something that operates like a contagious disease? Even if we accept that passive sympathy somehow becomes active sympathy, we still need to spell out how that is possible.

We could appeal to the second meaning of cultivation for guidance: once we expose ourselves to these feelings of sympathy, we must reflect on them and attend to them to make them active. Fahmy, for example, suggests that we must 'become aware of our natural sympathetic responses' in order to cultivate them (2009: 38 ). Perhaps once we are in the sick room, we must start reflecting on our sympathy when we feel it and the process of reflection will then allow us to subject our feelings to reason. Yet if these feelings are as pathological as Kant seems to claim, how would reflecting on them or attending to them make them practical or active? Kant claims that these are feelings we might be unable to resist, so he seems to suggest that they might be overwhelming. Going to places where we are likely to be emotionally overwhelmed seems like a particularly bad strategy for cultivating an emotion we are supposed to be able to subject to reason and moral principles. Kant surely holds (rightly or wrongly) that we have difficulty reflecting and reasoning when we are emotionally overwhelmed. It seems odd that he would recommend that we intentionally put ourselves in situations where we are likely to be emotionally overwhelmed so that we can then reflect - something we will be unlikely to do well - on the emotions that we are feeling. Again, Kant is clear that the risk of being emotionally overwhelmed is not an excuse to avoid going to these places; our duty to help remains and this is a risk we have to take. Accepting this risk, however, does not entail that we will cultivate sympathy while we are in the sick rooms and prisons. If we go to sad places enough, we might eventually stop being overwhelmed, but this might be the result of becoming desensitized. We may become used to the painful sights we encounter and they no longer bother us as they once did, but this would not mean that we have cultivated or refined our sympathy. If anything, we may become less sympathetic. ${ }^{17}$ Additionally, Kant sometimes suggests that attending to a feeling will strengthen it, as we saw in his remarks on the moral feeling and conscience. If we attend to or reflect on pathological sympathy, it seems we might only strengthen it rather than refine it, which is the opposite of what we want. As Weber argues, sometimes making 
sympathy more discerning requires having more of a 'filter' for our feelings (2003: 198). But this requires limiting our natural sympathetic feelings rather than encouraging them. There seem to be problems explaining how to read the claim about cultivating sympathy in section 35 no matter which meaning of cultivation we try to apply.

Besides the interpretative ambiguity in section 35 , Kant raises the possibility in the second Critique that sympathy poses a very serious danger of a selfcongratulatory cast of mind $(5: 84-9)$. He argues that one's moral disposition should be to act from duty and 'not from voluntary liking nor even from an endeavour he undertakes unbidden, gladly and of his own accord' (CPrR, 5: 84). Those who aim for a kindly disposition produce in themselves 'a frivolous, high-flown, fantastic cast of mind, flattering themselves with a spontaneous goodness of heart that needs neither spur nor bridle ... and thereby forgetting their obligation' $(\operatorname{CPr} R, 5: 85)$. Kant specifically warns that cultivating this disposition risks locating 'the incentive [of morality] pathologically (in sympathy or self-love)' (ibid., emphasis in original). We are tempted to imagine ourselves as so good-hearted that we do not need the 'yoke' of duty (ibid.). Kantian moral agents are of course always faced with the possibility of mistaking inclination for duty, but here Kant seems to think that striving to be good-hearted increases that risk. We can see why: this cast of mind causes a person to think that she need only listen to her heart in order to do the right thing rather than listening to the moral law. If Kant thinks this danger is real, it would be odd for him to recommend that we should intentionally expose ourselves to it.

Those who argue in favour of the cultivation view will object that there is no danger here. Kant's concern is that we mistakenly make sympathy the determining ground for the will, but the cultivation view can argue that we can cultivate sympathy without acting from sympathy. The problem is that given the particular danger of the cast of mind he describes above and Kant's insistence that we cannot know the depths of our hearts, it seems unlikely that he would recommend that we engage in behaviour that will blur the boundaries between motivations of duty and sympathy. ${ }^{18} \mathrm{He}$ poses the question: 'How would a man ascertain whether his joy at the rescue of an unfortunate family stems from sympathetic, pathological fellow-feeling, or from pleasure at the fulfilment of his duty?' (L-Eth, 27: 624-5). Kant's worry is a familiar one: how do I know, given that it is hard for me to know my own motives, if I visit a nursing home out of duty, because of warm sympathetic feelings, or because doing so allows me to praise myself as a good-hearted person. If we strive to be good-hearted, we not only face the temptation to let sympathy rather than duty determine 
our wills, but we also risk thinking that we are so sympathetic that our hearts naturally lead us to do the right thing without the command of duty. There is no way to protect ourselves from this risk if we intentionally expose ourselves to situations where we know our powerful sympathetic feelings will be aroused.

We could of course look beyond section 35 to support emotional cultivation. Perhaps instead of cultivating particular emotions, we must instead cultivate our emotional sensitivity. This claim is consistent with the duty of self-perfection, since refining our emotions is part of raising ourselves from animality to humanity. One passage that seems to serve this purpose is the section on sensitivity in the Anthropology: ${ }^{19}$

Sensitivity ... is a faculty and a power which either permits or prevents the state of pleasure as well displeasure from entering the mind, and thus it possesses choice. On the other hand, sentimentality is a weakness by which we can be affected even against our will, by sympathy for others' condition who, so to speak, can play at will on the organ of the sentimentalist ... for the man who wants to spare his wife or children difficulties or pain must possess ... delicate feeling ... and delicacy of his sensation is necessary for generosity. (7:236, emphasis in original)

This passage might seem to advocate cultivating emotional sensitivity, yet here sensitivity sounds like another version of sympathy. In Kant's own example, the husband must have enough 'delicacy' to judge what his wife's responses will be in order to spare her pain. This means he must be sympathetic to her; he must be able to put himself in her place. Indeed, the contrast to sensitivity is sentimentality, which Kant describes later in the passage as 'ineffectual sharing of one's feelings in order to appear sympathetically in tune with the feelings of others' (Anth, 7: 236). The distinction between sensitivity and sentimentality seems to mirror the distinction between active and passive sympathy. Even if we grant that Kant recommends that we cultivate sympathy, it may be sui generis in Kant's view (cf. Borges 2008: 53-5). The fact that sympathy can be morally valuable does not then allow us to conclude that we should cultivate emotional sensitivity in general.

Additionally, the appeal to sensitivity might undermine rather than support cultivation. The first mention of sensitivity in the Anthropology appears in book I in the general remark on outer sense. Kant claims: 'One can call the capacity for sensation that comes from strength delicate sensitivity [and] 
that coming from the subject's weakness ... tender sensitivity' (7: I 58 , emphasis in original). He describes tender sensitivity as arising from the subject's 'inability to withstand satisfactorily the penetration of influences into consciousness', which causes him to attend to these influences 'against his will' (ibid.). We can see how this sensitivity works by thinking of the overly sensitive person - someone who has no barriers to other peoples' suffering. She does not, in Kant's words, have the ability to 'withstand satisfactorily the penetration' of the suffering of others from grabbing her attention (ibid.). The overly sensitive person feels too much; she is overwhelmed by the painful sympathetic feelings that we have trouble resisting (the ones we might feel in the debtors' prison or sick room). As such, developing sensitivity will require developing her capacity to resist the pain of others from overwhelming her. The antidote to feeling too much is not to feel better or practical emotions; it is to feel less.

So far I have tried to show that the primary textual evidence for emotional cultivation is not as straightforward as it seems. We should not expect a set of instructions from Kant, but the fact that he says almost nothing about how to cultivate our emotions is puzzling. Given this missing discussion and the interpretative ambiguity in the cultivation passages, I think there is at the very least reason to revisit the claim that Kant thinks we should cultivate (non-specialized) emotions. One of the difficulties of determining where Kant stands on cultivation is that his views about emotions are notoriously complex. Does Kant think that emotions are physiological like pleasure and pain (cf. Sorensen 2002; Borges 2004, 2008; Deimling 2014; Frierson 2014 a, b) ? ${ }^{20}$ Are they something more complex that tracks value ${ }^{2 \mathrm{I}}$ Additionally, we still face the problem of explaining Kant's ambivalence: why does he have both positive and negative things to say about emotions? In what follows, I will offer an account of emotions that can explain Kant's ambivalence about them. Armed with this account, we can then revisit the question of emotional cultivation.

\section{What are Emotions?}

I will leave aside Kant's more specialized emotions such as moral feeling or respect and focus on emotions like joy, sadness, fear and anger. In the Anthropology, Kant categorizes emotions like these as pleasures and pains, and they are, as he rather mysteriously puts it, ways in which 'we feel our life' (7: 23I). ${ }^{22}$ The pleasure and pain Kant refers to is not just physical; it includes feelings like enjoyment and boredom. ${ }^{23} \mathrm{He}$ writes: 'Enjoyment is the feeling of promotion of life; pain is that of a hindrance of life' (ibid.). Kant argues that enjoyment drives me to 'maintain' the state I am in and pain impels me to 'leave' that state (ibid.). He then makes the somewhat 
controversial claim that enjoyment and pain exist in a 'continuous play of ... antagonism': we move from one state to the other at various times (ibid.). Pleasures fade and pains arise simply given the nature of our changing circumstances. I might, for example, enjoy a lively conversation for a while, but as the night progresses, I get bored or tired. The fact that I get bored with the conversation will motivate me to try to find a new and more pleasurable activity.

On Kant's view, we not only experience enjoyment and pain, we are able to experience them as enjoyment and pain. ${ }^{24}$ We remember past joy and suffering, we can anticipate future joy and suffering, and we can compare both of those to our present joy and suffering. ${ }^{25}$ Pessimistically, Kant writes that this ability is 'precisely what makes us miserable. Because this reflecting is not attached to animals, they are also never miserable' (L-Anth, 25: 247-8). ${ }^{26}$ We need not defend Kant's views about the emotional states of non-human animals to see what he means here. An animal might feel fear, but it cannot identify its feelings as fear. It also cannot focus its own attention on those feelings. A frightened cat, for instance, is focused on trying to flee, hide or defend itself. Its attention is on these activities, but not on its own feelings. Humans feel fear as fear rather than just some unpleasant or uncomfortable sensation.

Since we can identify our emotions as well as experience them, they are objects of our attention in a unique way (cf. Deimling 20I4: II3). Emotion (GemüthsBewegung) $^{27}$ is a 'feeling of pleasure or displeasure that draws our entire attentiveness to it' ( $L$-Anth, 25: I340). I can notice other kinds of sensations without my entire attentiveness being drawn to them - I can, for example, notice the soreness in my lower back or the murmur of conversation down the hallway without it commanding my attention. Of course, some kinds of physical pain, sounds and images do command our attention, particularly if they are severe, loud or obvious. Yet, as Kant suggests here, emotions are sensations that command our attention even if they are not particularly strong. I do not notice that I feel joy or sadness as I notice my lower back pain. If a friend tells me happy news, my joy for her arises instantly - I smile, the tone of my voice changes, and I am delighted and giddy. Emotions have the ability to crowd out other sensations (fear can, for example, mask pain), they can change our whole demeanour (as Kant points out with anger), ${ }^{28}$ and they can influence the way we experience the world (boredom can make us feel like we are dying a slow death). ${ }^{29}$

Kant's point here is not that an emotion has to be overpowering in order for it to command our attention; it is rather a defining characteristic of 
emotions that they can command our attention in this way. He expressly denies that even affects - which are usually taken to be Kant's example of overpowering emotions - are characterized by their strength: 'Generally speaking, it is not the intensity of a certain feeling (Gefühls) that constitutes the affected state (Affekts), but the lack of reflection in comparing this feeling with the sum of all feelings (of pleasure or displeasure)' (Anth, 7: 254). Kant elaborates with the example of the rich man whose servant breaks a glass. The rich man is given over to his pain because he cannot 'compare this loss of one pleasure with the multitude of all the pleasures that his fortunate position as a rich man offers him' (ibid.). If it is not the intensity of the rich man's sorrow that prevents him from comparing it with all his pleasures, then what is it? For Kant, it is the fact that emotions command our attention. When the rich man sees the broken glass, he immediately feels its loss and in that moment he cannot call to his mind any of the other things that make him fortunate and happy. The rich man 'gives himself over to this one feeling of pain', which is why 'he feels as if his entire happiness were lost' (ibid.). On my reading, this is a distinctive feature of emotions on Kant's view: emotions command our attention with a kind of immediacy.

One could object here that Kant's discussion of the rich man appears in the section on affects, and so my reading does not apply to emotions in general. Yet in the Anthropology Kant claims that affects belong in the faculty of feeling section rather than the faculty of desire section where they actually appear $(7: 235)$. He discusses them along with passions because he thinks the two are easily confused. Affects share some features with emotions and some features with passions, but scholars have said far more about their relationship to the passions. What do they share with emotions? My interpretation can answer this question: they both command our attention, just in different ways. Affects are a subset of emotions that 'transgress the boundaries of the human being's inner freedom' (Anth, 7: 235). While all emotions command our attention, affects are more disruptive to inner freedom. This distinction should seem familiar: I can be angry without being overcome with anger. Regular anger commands my attention, but not to such an extent that it precludes me from thinking straight. Anger as an affect, however, can reach this level; people can become so angry that they 'see red' or fly into a rage. Even if regular anger grabs my attention, I am still capable of redirecting my attention. Anger as an affect prevents me from redirecting my attention. As a result, it directs my mind and thus transgresses inner freedom. I will return to this topic in more detail, but for now, my main aim is just to show that emotions command our attention and affects 
share this feature with them. The difference is that affects prevent us from redirecting our attention while regular emotions do not.

If emotions command our attention, this can help explain Kant's ambivalence about them. First, it is clear that they can disrupt our mental composure: since they marshal our attention, they make it difficult for us to think clearly. Second, because emotions can command our attention, they can serve the more positive roles that Kant attributes to them.

\section{Emotions Disrupt Mental Composure}

It is easy to assume that Kant thinks emotions disrupt our mental composure because they are non-rational or irrational forces that overwhelm our reason. I want to suggest that his story is a bit more nuanced. On Kant's view, all emotions threaten animus sui compos (what I will call strength of mind). Kant uses this phrase in discussions of self-governance, but also in discussions of the affects. In the Metaphysics of Morals, he argues that inner freedom (which is necessary for virtue) requires 'being one's own master ... (animus sui compos) and ruling oneself' (6:407, emphasis in original). The phrase first appears in the Anthropology in the section on the voluntary consciousness of our representations. According to Kant we become conscious of our representations by either 'paying attention to (attentio) or turning away from (abstractio) an idea of which I am conscious' (Anth, 7: I3 I, emphasis in original). We know roughly what paying attention means, but what does it mean to turn one's attention away from an idea? Kant describes abstracting as 'stopping a representation of which I am conscious from being in connection with other representations in one consciousness' (ibid.). When we abstract from a representation, we voluntarily turn our attention away from the representation. Being able to abstract from a representation 'demonstrates a freedom of the faculty of the mind in having the object of one's representations under one's control (animus sui compos)' (Anth, 7: I3 I, emphasis in original). Kant then gives the example of someone who cannot abstract: 'The suitor who could make a good marriage if only he could overlook the wart on his beloved's face or a gap between her teeth' (Anth, 7: I32). ${ }^{30}$ The suitor cannot abstract from his beloved's imperfections because he cannot stop himself from seeing those imperfections as connected to her suitability as a marriage partner even though they are unconnected. In this way, the suitor lacks 'freedom of the faculty of thought and the authority of the mind' because he cannot control the way he attends to his own representations.

Animus sui compos appears again in the discussion of the affects. Kant describes an affect as 'surprise through sensation' that interrupts 
'the mind's composure (animus sui compos)' (Anth, 7: 252). Since Kant uses this phrase in his description of affects and in his description of abstraction, I think we gain clarity by reading these passages together. An agent who can abstract shows that she has a certain kind of control over her own mind and affects disrupt the control that the ability to abstract demonstrates. The ability to abstract requires the ability to redirect our attention, which is what affects in particular prevent us from doing. It is not merely the intensity of the affect that disrupts the mind's composure; it is rather the fact that they can marshal our attention in the way that they do. We tend to think of abstraction in terms of directing our minds away from thoughts or mental images, but we can also abstract from our sensations of pleasure and pain. Kant makes this clear when he discusses hypochondria. ${ }^{3 \mathrm{I}}$ Here again Kant says that human beings have a 'peculiar characteristic' where they can 'strengthen or sustain a feeling by paying attention to certain local impressions' (Anth, 7: 2I2). The problem with the hypochondriac is that his physical sensations cause him anxiety from which he cannot abstract. As Kant points out, the hypochondriac can 'either by intentional abstraction or abstraction caused by other distracting occupations ... weaken the feeling, and if abstraction becomes habitual, make it stay away completely' (Anth, 7: 2I2). The problem with the hypochondriac, on Kant's view, is that he cannot stop himself from taking his physical sensations as signs of some real or imagined illness. He cannot, in other words, see his sensations as just sensations. Because the hypochondriac's anxiety occupies his attention, he then interprets his sensations as symptoms, which then serves to strengthen his anxiety. Abstraction, according to Kant, would break this cycle and break the hold that anxiety has over his attention.

Now we can see why Kant might worry about emotions. Emotions and affects challenge our ability to abstract because they command our attention. Although emotions do not preclude abstraction, they do make it difficult: we have to make a concerted effort to redirect our attention when we are angry, sad or bored. Affects prevent us from redirecting our attention altogether. Inner freedom is necessary for virtue and animus sui compos is required for inner freedom. The suitor, the rich man and the hypochondriac all lack this strength of mind to varying degrees. On Kant's view, we can explain these cases because the emotions involved - disgust, sorrow and fear - capture each person's attention to such an extent that they are either unable to redirect their attention or have difficulty doing so. This power that emotions have is, for Kant, understandably worrisome: the fact that emotions can grab our attention does not mean they will grab it in the right ways. 


\section{Emotions as Surrogates for Reason}

It is clear that emotions can disrupt the mind's composure because of their ability to marshal our attention, but this feature can also explain why Kant thinks they can serve as a surrogate for reason - what Sherman calls the 'faute de meiux' view about emotions (2014: 20). In the Anthropology, Kant claims that some affects (he names compassion) can 'handle the reins provisionally, until reason has achieved the necessary strength' (7:253, emphasis in original). In this way, affects can 'enliven us' even before we are moved by practical reason (7: 254). This claim should be more puzzling than it initially seems given some of Kant's descriptions of emotions. Throughout his writings, Kant insists that we are not to allow inclinations to 'play the master' over us (MM, 6: 408). We can see how our desires might play the master over us, since they move us to act in specific ways for specific things. ${ }^{32}$ But affects are, in Kant's words, 'blind' and 'imprudent' (Anth, 7: 253). If they are totally thoughtless or aimless, how are they capable of mastering us in the first place? Surely they can crowd reason out - my fear might be so strong in a particular moment that I cannot quite pull myself together. ${ }^{33}$ But our affects subside: they are like 'a drunkenness that one sleeps off' (ibid.). If affects are thoughtless in some strong sense, why does Kant think that they can sometimes act as a 'temporary surrogate of reason' (ibid.)?

If my reading of Kant's view of emotions is right, we can better see how they can handle the reins at least provisionally. Affects share with emotions the ability to command our attention. In the Anthropology lectures Kant asks, 'If we are supposed to overcome affects, why did nature give them to us then?' (25: I342). He answers that nature gives affects to our animality: 'For in the state of animality, where all the first human beings were, the affects served to double all of their powers and provided for their preservation' (L-Anth, 25: I343). They are, as Kant puts it, 'a spur to activity, as it were, in order to develop our humanity' (ibid.). These explanations are consistent with Kant's claims that emotions are types of pleasures and pains, and that the antagonism of the two moves us to do things. But this antagonism is not just an 'incentive to activity', but also one that allows us 'to progress toward what is better' (Anth, 7: 235). Since we can both experience our emotions and also compare, remember and anticipate our emotions, it seems this is the way in which they 'double our powers' and 'progress toward the better'. I can, for example, experience enjoyment in playing a game, identify it as enjoyment and remember that enjoyment. Remembering it allows me to anticipate it again in the future and will spur me to seek out that enjoyment. As Kant describes it, what 'urges me to leave my state ... is 
disagreeable ... just as what drives me to maintain my state ... is agreeable' (Anth, 7: 23I). This is one way that our emotions can act as a provisional form of reason: they are unprincipled and unreliable, but they enliven us to avoid pain and seek pleasure. In this way, they can mimic prudential reasoning. Fear, for example, can get me out of danger in a particular situation, and it can also help me avoid danger in the future. The reason emotions have this ability on Kant's view is because they command our attention in the way they do. ${ }^{34}$ In order for emotions to act as a surrogate for reason, they have to be sufficiently reason-like. Emotions and the dictates of reason share a similar kind of salience; we are aware of them with a kind of immediacy. Emotions are also motivating even though they are unreliable and sometimes unpredictable. This interpretation can explain why Kant thinks emotions can both disrupt the mind's composure and handle the reins until reason is strong enough to take over.

If emotions can serve as reason's surrogate in this way, we can explain Kant's more positive claims about them. When we return to section 35 , we can see why passive sympathetic feelings are 'one of the impulses that nature has implanted in us to do what the representation of duty alone might not accomplish' (MM, 6: 457). On my reading, Kant is talking about the natural sympathetic feelings that belong in the same category as joy or sadness. Feelings of sympathy can lead me to help others who are suffering even when I do not act on the basis of moral principles. Since emotions are sufficiently reason-like, they can lead us to do things that turn out to be consistent with virtue. ${ }^{35}$ Nature has implanted these feelings in us and they remain with us even after reason develops, which is why our emotions and reason can sometimes match up the way they do. Because emotions at some point functioned as a surrogate for reason, they and reason will end up calling our attention to the same features of the world. Additionally, Kant claims that there is 'something agreeable' about being on the 'edge' of an affect (L-Anth, 25: 616). This edge happens when we feel an emotion, but are not overwhelmed by it. ${ }^{36}$ Anger, for example, can be 'valiant' and 'sublime' because it can 'harmonize with principles, and without deliberation, give weight to reason' (ibid.). Here Kant seems to be thinking of what we would call righteous anger. Additionally, in the third Critique he claims that 'courageous affects' like anger can arouse 'the consciousness of our powers to overcome any resistance' $(5: 272)$. Why does it feel good when reason and emotion harmonize? Kant thinks that in these moments we are reminded that we have the strength and courage we need for virtue. These moments give us 'confidence in our own capacity for resistance 
against evil' and 'strength and resolution' (CPJ, 5: 273). Feeling righteous anger makes us feel powerful because our humanity and animality are for a brief moment united. ${ }^{37}$ These moments occur not because our emotions have been properly trained or habituated, but because they used to do the job that reason now does and because they can still do that job even though reason is now in charge.

\section{Revisiting Cultivation}

Armed with this account of emotions in Kant's theory we can revisit the question about emotional cultivation. Given the ambiguity of the textual evidence in support of the cultivation view and the account of emotions I have offered here, I conclude Kant denies that we should cultivate emotions. Kant directly anticipates the question of cultivation in the same remarks where he talks about the characteristics of emotions. He thinks the question arises: 'Whether the affects and passions are good or bad, therefore whether one must promote or subdue them?' (L-Anth, 25: 6I6). One might expect that Kant would give the traditional answers that he gives in the published Anthropology about affects and passions challenging the sovereignty of reason, yet his answer is different. He simply claims that affects and passions belong to our animality: 'Affects and passions are means of exerting our powers in animality, and take the place of deliberation' ( $L$-Anth, 25:6I 7$)$. Once reason takes over, 'we are not justified in using what was an incentive with animality also as an incentive with reason' (ibid.). ${ }^{3}$ Even though emotions can serve and likely have served as stand-ins for deliberation, once reason comes into its power, we cannot then go back to them. We can see why, given the arguments I made in the previous section about animus sui compos. If emotions have the ability to capture our attention, it would be inconsistent for Kant to recommend that we increase our receptivity to them or try to induce them. In doing so we would knowingly put ourselves in a position to disrupt our animus sui compos, which is necessary for virtue. As such, Kant rightly thinks we need to develop our strength of mind so that we can resist the pull of emotions on our attention. None of this means that we should stamp out our emotions, but it also seems that we ought not cultivate them. Instead, Kant seems to think we should develop the right orientation towards them.

We see a glimpse of what this might look like in Kant's remarks about sensitivity. Recall that the sentimental person has an 'inability to withstand satisfactorily the penetration of influences into consciousness', which causes him to attend to these influences 'against his will' (Anth, 7: I 58 ). As such, the sentimental person has a 'moody' disposition in which 
he is disposed to 'attacks of joy and grief for which the subject himself can give no reason' (Anth, 7: 235). In the Lectures on Ethics, Kant claims that the remedy for sentimentality is developing proper sensitivity. There he defines sensitivity as a 'receptivity of the mind both for agreeableness and convenience, and also for their opposite, the pain and trouble of life' (L-Eth, 27: 645). Proper sensitivity on Kant's view requires 'judicium discretum ... to recognize what pertains to the agreeable or disagreeable, in regard both to myself, and others, and what is able to arouse either pain and trouble or pleasure' (L-Eth, 27: 645, emphasis in original). It is this discerning judgement (rather than sympathy) that must 'be cultivated' (ibid.). Again, we see that it is not the strength of pleasures and pains that Kant is worried about. It is the fact that we do not have discerning judgement about them. What would discerning judgement about emotions look like? As we have noted, Kant provides the following example 'if I receive a letter, and it has at once aroused anger in me; if I answer right away, I let my anger be very plain; but if I can put it off till the following day, I shall view the matter from a different standpoint' (L-Eth, 27: 366). Notice that the person receiving the letter need not be overreacting - perhaps the letter really was insulting. Nonetheless, she has the strength of mind to know that her anger will influence her response because it marshals her attention. She directs her attention away from her anger and entertains the possibility that there might be another viewpoint her anger is not allowing her to consider. Again, this does not mean that her anger is unjustified or uncalled for. Keeping her anger in perspective means that she realizes that her anger might be a response to some features of her situation, but that it might not represent the situation accurately or fully. To realize this, she needs the animus sui compos and control of her attention that Kant recommends. On my view, Kant recognizes that a good heart requires a good head. ${ }^{39}$

\section{Notes}

I Baron (I995), Sherman (I997), Guyer (I993, 2008), Fahmy (2009) and Baxley (2010) argue for different versions of this view. All references to Kant are taken from the Akademie volumes. I use the following abbreviations and translations: Anth = Anthropology from a Pragmatic Point of View (Kant 2007), L-Anth = Lectures on Anthropology (Kant 20I2), CPrR = Critique of Practical Reason $($ Kant I996), L-Eth = Lectures on Ethics (Kant 1997), MM = Metaphysics of Morals (Kant 1996), CPJ = Critique of the Power of Judgement (Kant 2000).

2 It is important to note that Kant does not use only one term for emotions; he uses a family of them. This, of course, does not preclude us from talking meaningfully about emotions as a category. For further explanations, see Borges $(2004,2008)$, Deimling (20I4) and Frierson (2OI4a, b).

3 Borges (2008) has evinced a sceptical view of emotional cultivation as well, though our accounts of emotions differ. 
4 For arguments in favour of cultivating specialized moral emotions, see Cohen (2016), Borges (2004), Geiger (20II) and Guyer (20IO). Even if we can and should cultivate these feelings, there is no reason to assume that this applies to emotions generally. Kant typically treats these feelings as separate from regular emotions. See, for example, the discussions of the moral pre-conditions $(M M, 6: 399-403)$, the discussion of respect in the second Critique (5:74-8I) and the remarks on moral feeling and the sublime (CPJ, 5: 265-76).

5 Baron, for example, argues that the cultivation view can explain how Kant can 'attribute positive value' to inclinations (I995: 205). Sherman argues that 'cultivating this more diverse palette [of emotions] is especially important for the project of virtue' (I 997 : I 55 ).

6 Sherman uses this term (I997: I49).

7 For extended discussions of the centrality of the motive of duty see Herman (I993: I-6), Baron (I995: I46-70), Guyer (2000: 287-303); Weber (2007), Wood (2008: 24-42).

8 Cohen goes on to argue that Kant believes we ought to cultivate the inclinations of love and honour, but these feelings are different from average emotions (2016: 5 I3).

9 Papish, for example, writes that we can 'further strengthen these feelings if we not only consider and wonder at their source but also actively attend to and strive to prolong our experience of these feelings' (2007: I3I). Papish's account of habituation, although instructive, applies primarily to desires. Kant is clear in the Anthropology that non-specialized emotions are not desires; they are types of pleasures and pains. As such, it is unclear that this sort of habituation would cover the kinds of emotions that Kant has in mind.

Io Kant sometimes expresses scepticism about this idea, however. He refers to 'more refined feeling' as a 'meaningless epithet' (CPJ, 5: 266).

I I Kant uses similar language in the second Critique, though there he claims that 'we call ... joys and delights more refined because they are more under our control' $(5: 24)$. Here it is unclear if the feelings are better or if they are simply more controlled.

I2 While their accounts are by no means univocal, Baron (I995), Sherman (I997), Guyer (1993, 2010), Fahmy (2009) and Borges (2004) all cite this passage as evidence that Kant believes some emotions can be cultivated. Borges (2008) argues that sympathy can be cultivated, but that cultivation does not extend to emotions more generally.

I3 As Denis points out, Kant's disagreement with the Stoics is typically that while they get the basic structure of morality right, they go too far in thinking that human beings can (and should) accomplish what the sage accomplishes (2000: 60-I).

I4 Guyer (20I0: I46-7); Baron (I995: I7I-2); Sherman (I997: I45-50).

I 5 Fahmy interprets this passage similarly, but she sees resisting the temptation to avoid places where people suffer as a 'first step' to the cultivation of sympathy (2009: 38 ).

I6 Active sympathy is the 'capacity' (Vermögen) or 'will to share in others' feelings' (MM, 6: 456). Passive sympathy is a 'receptivity (Empfänglichkeit), given by nature itself, to the feeling of joy and sadness in common with others' (which may 'therefore be called "aesthetic" (ästhetisch)' (ibid.). In the Anthropology, Kant claims that one 'sympathizes with others by means of the power of imagination' (7:238). Similarly, in the Lectures on Ethics, he writes that 'moral sympathy is imprinted on all' and it is by means of moral sympathy that one can 'put himself in the other's place' (27:65). Kant lists the powers of the imagination as one of the mental faculties that we are to cultivate under the duty of self-perfection. He lists it under the 'powers of soul' (Seelenkräfte), which includes 'memory, imagination and the like, on which can be built learning, taste (internal and external embellishment) and so forth' (MM, 6: 445). As both Wood and Fahmy stress, translating Teilnehmung just as 'sympathy' misses the element of 'participation' or 'sharing' that is involved (Wood 2008: 176-8; Fahmy 2009: 43-4). If they are correct, 
we might wonder whether a duty to cultivate sympathy is a duty to cultivate sympathetic feelings at all and instead a duty to cultivate the powers of imagination we have to put ourselves in others' circumstances.

I7 My thanks to an anonymous reviewer for asking me to clarify this point.

I8 Kant mentions the difficulty of knowing our own hearts in the following passages: $M M$, 6: 44I and 447; L-Eth, 27:365.

I9 Baron (I995: I96), Sherman (I997: I68-9) and Fahmy (2009: 39-4I) appeal to the sensitivity passage in this way.

20 Borges, for example, argues that emotions are more physiological for Kant and is sceptical of cultivation (2008: 56-9).

2I Deimling argues that emotions are pleasures and pains that 'track' values (20I 4: I I 8-20). Sherman argues that emotions disclose values (I997: I46).

22 Frierson notes this feature of emotions (20I4a: I69-70).

23 Borges explains the complexities with the physiological underpinnings of Kant's account of emotions (2004, 2008).

24 Deimling calls this the 'value tracking' feature of emotions (2OI4: II4). I think the terminology of value suggests something more than Kant means here, so I will not use the same term.

25 Deimling explains this point in terms of 'simple' and 'complex' affective states (2OI4: II4-I5).

26 Likewise, 'Animals are capable of neither distress nor joy, because they cannot reflect about their state' (L-Anth, 25:474).

27 Clewis translates GemüthsBewegung in this sentence as 'mental movement'. Here Kant is talking about emotions generally and not just affects.

28 '[If] I receive a letter, and it has at once aroused anger in me; if I answer right away, I let my anger be very plain; but if I can put it off till the following day, I shall view the matter from a different standpoint' (L-Eth, 27: 366).

29 Boredom is a 'void of sensations' and feels to us like a 'slow death' (Anth, 7: 233).

30 Sherman argues that this passage reveals a flaw in Kant's view: 'What is comical here is Kant's wistful attempts to deny that an important value of the testimony of the emotions is precisely its rawness' (1997: I7I). Sherman thinks that Kant fails to appreciate the way emotions can alert us to features of the world. As I read it, the passage is pointing out that the suitor fails to see the qualities of his beloved that are really important and instead is fixating on representations that should not matter.

3 I Kant specifically uses hypochondria to illustrate the inability to abstract in the Lectures on Anthropology (25: 489). Deimling uses this example to illustrate the distinction between simple and complex feelings (20I4: I I 5 ). I am unsure whether Kant is making the distinction Deimling appeals to, so I will not presuppose it.

32 I draw inspiration here from Schapiro's discussion of the nature of inclinations (2009).

33 For a more detailed discussion of the relationship between affects and practical reason, see Frierson (2OI4b: I03-6).

34 The precise way in which affects are motivating is unclear. That is, affects might motivate because they cause desires or they might motivate as instincts motivate. For further discussion, see Frierson (2OI4b: IO2-6).

35 Reath argues that inclinations have the appearance of providing justified reasons for action (I989: 297-300). The account I offer here may add further support and clarification for this position. My thanks to an anonymous reviewer for pointing out this connection.

36 For further discussion of these moments as examples of enthusiasm, see Sorenson (2002: II9-20). 
37 Kant refers to this same moment in the Doctrine of Virtue as a 'momentary, sparkling phenomenon that leaves one exhausted' (MM, 6: 409).

38 Additionally, 'If the human being has emerged from animality, he does not need the affects anymore and must suppress them' (L-Anth, 25: I343).

39 I am very grateful to two anonymous reviewers for their helpful feedback on this article. Mavis Biss, Laura Papish and Owen Ware read early versions of this paper and provided valuable comments. My many conversations with Jeremy Schwartz were integral to developing my thinking on this topic. I presented a shorter version of this paper at the I 2 th International Kant Congress and I would like to thank the audience there for their questions.

\section{References}

Baron, Marcia (1995) Kantian Ethics Almost Without Apology. Ithaca, NY: Cornell University Press.

Baxley, Anne Margaret (20I0) Kant's Theory of Virtue: The Value of Autocracy. New York: Cambridge University Press.

Borges, Maria (2004) 'What Can Kant Teach us about Emotions?'. Journal of Philosophy, IOI, I $40-58$.

- (2008) 'Physiology and the Controlling of Affects in Kant's Philosophy'. Kantian Review, I3, 46-66.

Cohen, Alix (2016) 'The Role of Feelings in Kant's Account of Moral Education'. Journal of Philosophy of Education, 50, $5 \mathrm{II}-23$.

Deimling, Wiebke (2014) 'Kant's Pragmatic Concept of Emotions'. In Alix Cohen (ed.) Kant on Emotion and Value (New York: Palgrave Macmillan), pp. Io8-25.

Denis, Lara (2000) 'Kant's Cold Sage and the Sublimity of Apathy'. Kantian Review, 4, $48-73$.

Fahmy, Melissa Seymour (2009) 'Active Sympathetic Participation: Reconsidering Kant's Duty of Sympathy'. Kantian Review, I4, 3 I-52.

Frierson, Patrick (2014a) ‘Affective Normativity'. In Alix Cohen (ed.) Kant on Emotion and Value (New York: Palgrave Macmillan), pp. I66-90.

- (20I4b) 'Affects and Passions'. In Alix Cohen (ed.) Kant's Lectures on Anthropology: A Critical Guide (Cambridge: Cambridge University Press), pp. 94-I I3.

Geiger, Ido (20II) 'Rational Feelings and Moral Agency'. Kantian Review, I6, 283-308.

Guyer, Paul (1993) Kant and the Experience of Freedom. New York: Cambridge University Press.

- (2000) Kant on Freedom, Law, and Happiness. Cambridge: Cambridge University Press.

- (2008) Knowledge, Reason and Taste: Kant's Response to Hume. Princeton: Princeton University Press.

- (2010) 'Moral Feelings in the Metaphysics of Morals'. In Lara Denis (ed.), Kant's Metaphysics of Morals: A Critical Guide (Cambridge: Cambridge University Press), pp. $130-52$.

Herman, Barbara (1993) The Practice of Moral Judgment. Cambridge, MA: Harvard University Press.

Kant, Immanuel (1996) Practical Philosophy. Trans. and ed. Mary Gregor. Cambridge: Cambridge University Press.

_ (I997) Lectures on Ethics. Ed. Peter Heath and J. B. Schneewind, trans. Peter Heath. Cambridge: Cambridge University Press.

- (2000) Critique of the Power of Judgment. Ed. Paul Guyer, trans. Paul Guyer and Eric Matthews. Cambridge: Cambridge University Press. 
- (2007) Anthropology, History, and Education, Ed. Gunter Zoller and Robert Louden trans. Mary Gregor, Paul Guyer, Robert Louden, Holly Wilson, Allen W. Wood, Gunter Zoller and Arnulf Zweig. Cambridge: Cambridge University Press.

(20I2) Lectures on Anthropology. Ed. Allen W. Wood and Robert B. Louden, trans. Robert R. Clewis, Robert B. Louden, G. Felicitas Munzel and Allen W. Wood. Cambridge: Cambridge University Press.

Papish, Laura (2007) 'The Cultivation of Sensibility in Kant's Moral Philosophy'. Kantian Review, I2, I 28-46.

Reath, Andrews (1989) 'Kant's Theory of Moral Sensibility: Respect for the Law and the Influence of Inclination'. Kant-Studien, 80, 284-302.

Schapiro, Tamar (2009) 'The Nature of Inclinations'. Ethics, I I9, 229-56.

Sherman, Nancy (I997) Making a Necessity of Virtue. Cambridge: Cambridge University Press.

- (2014) 'The Place of Emotions in Kantian Morality'. In Alix Cohen (ed.) Kant on Emotion and Value (New York: Palgrave Macmillan), pp. I I-32.

Sorensen, Kelly (2002) 'Kant's Taxonomy of Emotions'. Kantian Review, 6, I09-28.

Wood, Allen (2008) Kantian Ethics. Cambridge: Cambridge University Press.

Weber, Michael (2003) 'The Motive of Duty and the Nature of the Emotions: Kantian

Reflections on Moral Worth'. Canadian Journal of Philosophy, 33, I83-202.

- (2007) 'More on the Motive of Duty'. Journal of Ethics, II, 65-86. 